\title{
Fostering intercultural competence through videoconference exchange: using an external provider to match learners with trained native speakers and administer video calls
}

\author{
Alonso Varo Varo ${ }^{1}$
}

\section{Abstract}

his practical case presents the use of an External Provider (EP) as an alternative approach to the traditional telecollaboration setting where a partnership with a

foreign higher education institution is established. Usually, these partnerships involve language exchanges between learning partners who mutually practice each other's native language. Instead, an eight-week cross-cultural Virtual Exchange (VE) in Spanish between US college students studying Spanish and trained Colombian university students was organized through an external language platform to foster the US students' Intercultural Competence (IC). It is concluded that the use of an EP brings an undeniable level of flexibility to the organization of the VE, and makes manageable the integration of this type of program in higher education language classes. Additionally, this article assesses the value of this approach by looking at the effect of VE on the US students' selfassessment of IC after the videoconference exchanges. Data from quantitative surveys and student blogs show a significant increase in the students' IC after the program.

\section{Keywords: telecollaboration; external provider; intercultural competence; virtual exchange.}

1. Christopher Newport University, United States of America; alonso.varovaro@cnu.edu; https://orcid.org/0000-0003-1463-3151

How to cite this article: Varo Varo, A. (2021). Fostering intercultural competence through videoconference exchange: using an external provider to match learners with trained native speakers and administer video calls. Journal of Virtual Exchange, 4, 1-13. https://doi.org/10.21827/jve.4.35981 


\section{Introduction}

Given the growing importance of internationalization and diversity on our campuses and in our daily relations, a correct integration of IC into the 21st century higher education curriculum is critical (Deardorff, 2004) ${ }^{2}$. IC ${ }^{3}$ is understood as a set of abilities required "to perform effectively and appropriately when interacting with others who are linguistically and culturally different from oneself" (Fantini, 2009, p. 458).

One of the most common practices to incorporate IC development into higher education is telecollaboration, also called VE, online intercultural exchange, or collaborative online international learning (Liaw, 2006; O’Dowd, 2007; Vinagre, 2014). Telecollaboration is the "engagement of groups of learners in online intercultural interactions and collaboration projects with partners from other cultural contexts or geographical locations as an integrated part of their educational programmes” (O’Dowd, 2018, p. 1).

Despite its potential for the development of IC, the integration of telecollaboration into the curriculum remains marginal and challenging. Teacher-to-teacher relationships, course organization, technical issues, differences in timetables, matching of learners, workload, and curricular limitations are reasons for teachers to disregard the possibility of creating a telecollaboration project (see also Ferreira-Lopes, Bezanilla, \& Elexpuru, 2018). While some adjustments can relieve educators of the time burden that the organization of telecollaboration projects imposes (e.g. Helm, 2015; O’Dowd, 2018), there remains a need to develop sustainable instructional design models and to address the main barriers to the integration of telecollaboration in higher education (Ferreira-Lopes et al., 2018).

This practical case provides an account of student and instructor experiences using an EP as an alternative approach to the traditional, practitioner-led, telecollaboration setting where a partnership with a foreign higher education institution is established. Usually, these partnerships involve language exchanges between learning partners who mutually practice each other's native language. In this case, an eight-week cross-cultural VE between US college students studying Spanish and Colombian university students was organized through an external language platform, during which the US students spoke exclusively Spanish. This report evaluates the effectiveness of the use

2. This paper uses IC over other terms - intercultural communicative competence, cross-cultural awareness, cultural competence, ethno-relativity, etc.- as it is the most widely accepted in the literature.

3. Many descriptions have been provided since Byram's (1997) seminal definition. Fantini's (2009) conceptualization of the term is chosen here since it best fits the model of this study. 
of an EP, based on quantitative and qualitative results from students' self-assessments of IC before and after the videoconference exchanges.

\section{Context}

During Spring 2019, two sections of an advanced Spanish conversation course at a US public liberal arts university were selected to foster the students' IC through VE. This course was selected because of its significant cultural component and the students' appropriate level of communication skills (the majority of the students who sign up for this course rank at the intermediate high level, based on the ACTFL ${ }^{4}$ listening and oral proficiency guidelines). A total of 35 students were enrolled in the course, with 18 in one section and 17 in the other. The student distribution according to the number of years completed at the university level was the following: 1 freshman, 15 sophomores, 12 juniors, and 7 seniors. All students successfully passed a high intermediate Spanish class at the university level or had at least four years of high school Spanish.

Due to time, scheduling, and curricular limitations, a tandem partnership with a foreign higher education institution was disregarded. Instead, the services of an external language platform (further referred to as EP) were incorporated into the project. EP is a social enterprise that seeks to create opportunities for young people in Latin America. It connects language 'learners' (people around the world who want to practice conversational Spanish) with native speaking 'amigos' (students in Latin America who wish to gain flexible income opportunities) through one-on-one video call sessions. Thus, 'learners' and 'amigos' from different backgrounds interact and share their worldviews. EP offers these services to higher education institutions that seek to integrate videoconference exchange with native Spanish speakers into their class curriculums.

The role of the instructor (the author of this paper) during the process focused on the general organization of the course, task design, selection of cultural topics to discuss, design of the methodology for the study, and, partly, the students' preparation for the exchange. EP's role concentrated on organizing the videoconference exchanges. EP staff provided a handbook to guide students through the videoconference sessions, managed the scheduling of the virtual exchanges, matched the US students (learners) with Colombian native speakers around their same age (amigos), provided a toolkit to handle any possible technological issues, and sent reminders and feedback to the US students, including a link to the recorded sessions.

4. American Council on the Teaching of Foreign Languages 


\section{Objectives}

This case presents a new practice to incorporate telecollaboration and the development of IC in higher education courses by using an EP. The effectiveness of this approach is assessed by looking at the US students' perceptions on the use of the language platform as an EP and on their selfassessment of IC after the videoconference exchanges. Both qualitative and quantitative data were collected through pre-surveys, post-surveys, reflection blogs, and oral presentations.

\section{Project design}

This project was designed in collaboration with the EP staff during the semester prior to its implementation in Spring 2019 (Figure 1). During the first week of the semester, the instructor introduced the syllabus of the course and the platform to the class. All measures used in this study (videoconferences, reflection blogs, and oral presentations) were embedded, among other activities, in the syllabus as part of the graded components. Each measure came with a rubric so students had a clear understanding of the course expectations.

During the second week of classes, EP staff guided the US students through a short technical walk-through. In this session, the EP team explained the technical requirements for accessing the videoconferences (in this case, Google's free video chat service Google Hangouts, now Google Meet, was used). Also during this session, students' personal devices were tested for the technical requirements for supporting the exchange.

At this time, the instructor also introduced the research study to the students. Students were informed that the participation in the survey - and thus the research - was entirely voluntary, and non-participation would not affect their grades for the course. If students decided not to participate, their performances on the blogs, presentations, and conversation videos would not be part of the research data. Before taking the online survey, students were presented with an informed consent form where this information was reiterated.

In the third week of classes, the instructor provided students with a list of topics relevant to Colombian culture (Appendix 1). They were asked to give an account of their familiarity and knowledge about three of those topics. After class, students received a link to complete the IC pre-survey (Appendix 2).

Also in the third week, the EP staff gave students a digital copy of the Learner's Toolkit (Appendix 3). In this toolkit, students find a clear 'roadmap' of their journey with EP. First, students make the 


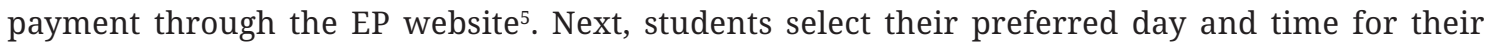
session through an online survey, after which they are matched with a Colombian native speaker based on the time preference of the 'learners' and the availability of the 'amigos'. Throughout the semester, the EP staff tried to maintain the same match for every student for all the sessions. The only exceptions were due to the need for rescheduling by some US students. Once the EP team found the right match for all participants, the US students received an email confirmation with the scheduled time and some personal information about their 'amigo'.

A total of nine 'amigos' participated in the sessions. Their ages ranged from 19 to 24 years old, and they were studying to obtain different bachelor's degrees. To become an 'amigo', students undergo a very selective recruiting process involving an online application and several rounds of interviews assessing skills like communication, problem solving, creativity, and responsibility. Once selected, the 'amigos' receive training from the EP staff, including mock calls, materials with the class curriculums that they will support, and individual and group sessions. They learn how to address specific situations, and receive tips on how to correct a learner, the speed of the conversation, how to make sure the learner is following, and how to provide feedback. The training program also includes a “mentoring program” where experienced 'amigos' train new 'amigos' on a 1-on-1 basis, providing personalized feedback based on the recordings of the video calls and the needs of each'amigo'. For this course specifically, the 'amigos' also received a toolkit (Appendix 4) with information about the topics of the sessions.

The first videoconference session took place during the fourth week of classes. One day before the session, students received a reminder email through which students either confirmed attendance or suggested three new time slots to reschedule. Five minutes before the scheduled time, students received a link to connect to the session. In this first exchange, 'amigos' and 'learners' got acquainted, chatting about their everyday lives, likes, and dislikes.

The second, third, and fourth sessions took place during weeks six, eight, and eleven. In each session, students discussed one of the topics they had selected during the third week of classes. They were also encouraged to review relevant vocabulary for the topic and to practice some questions that they wanted to ask their exchange partner, while being ready to be asked similar questions.

5. The US students paid 20 dollars for all four sessions. During the last two weeks of classes, 22 out of 35 students voluntarily completed a feedback questionnaire from EP. One question inquired about students' perceptions of the price of the service (cheap, fair, expensive). Nineteen students considered the price fair, one student thought it was expensive, and two thought it was cheap. Additionally, no negative feedback regarding the price or using a fee-paying service was reported through anonymous course evaluations or the provider's questionnaire. 
All exchanges were conducted in Spanish. It is important to note that the exchanges were all meant to be casual conversations about a cultural topic. While only one conversation partner was native in the target language, ultimately, both partners were learning about each other's cultures. The 'amigos' were allowed to point out recurrent Spanish grammar mistakes, but without diverting from the main conversation topic. 'Amigos' also occasionally used the chat feature in Google Hangouts to present new words to the learners or to address unexpected technical issues.

Figure 1. Timeline of project

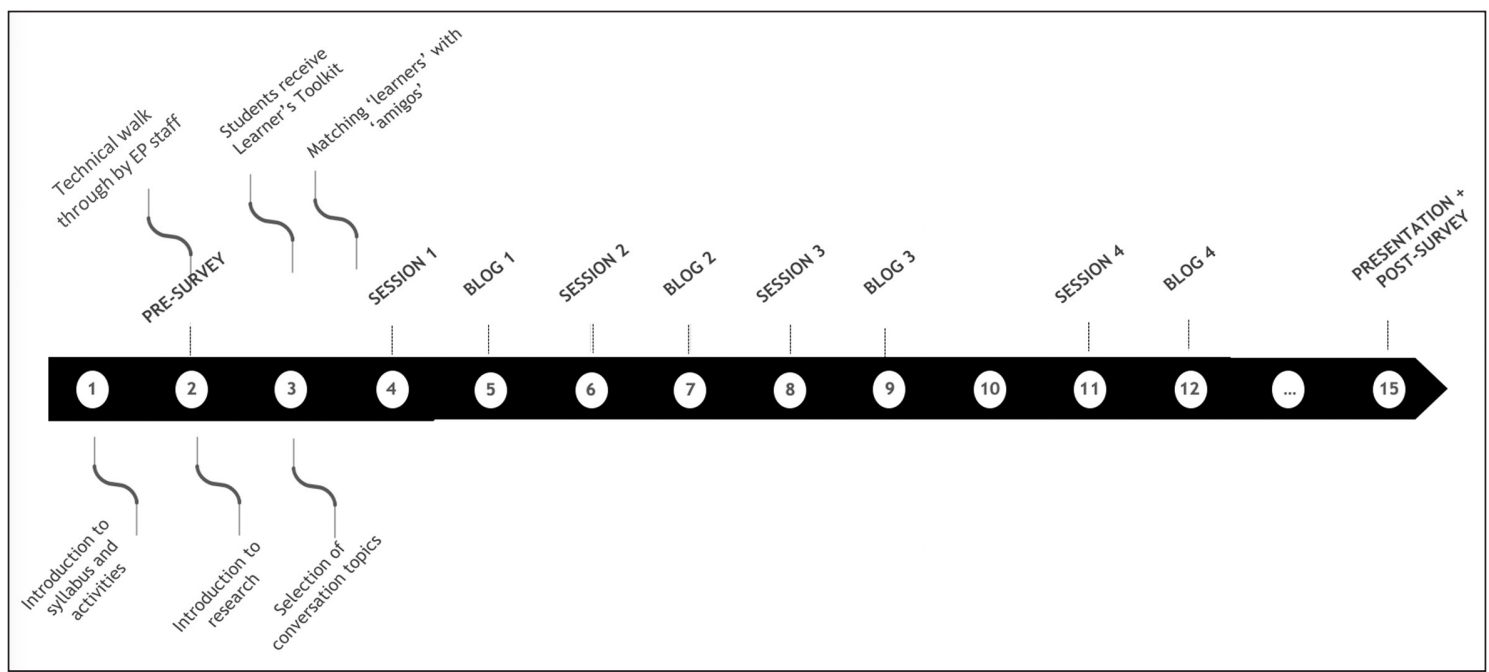

The duration of each session was flexible, but they had to last a minimum of 20 minutes, and the recommended time was 30 minutes. The average time of all sessions was 31 minutes. After every session, students could provide feedback about any personal or technical issues, and received an email including a link to the recorded session and a feedback report from their 'amigo'. In these feedback reports, 'amigos' provided a recap with new vocabulary and expressions that the US students learned throughout the exchange.

Within a week of each session, the US students wrote a 350-word blog entry about their exchange experience. Students were asked to reflect on the new perspectives and content that they had learned about the selected discussion topic. They were encouraged to reflect on how their exchange partner's beliefs, opinions, and standpoints were similar or different to the ones from their own culture and whether their exchange partner's reactions toward a specific topic of discussion was different from theirs. Based on these reports, during the last week of classes, the US students presented to the class 
their personal experiences throughout this cross-cultural exchange. Finally, the students completed the post-survey online during the last two weeks of classes. From a total of 35 students, 24 students completed both the pre-survey and post-survey.

\section{Evaluation}

To analyze the effects of video-exchange on IC of US college students, this study uses an adapted version of the Your Objectives, Guidelines, and Assessment (YOGA) form to assess IC (Fantini, 2000) ${ }^{6}$. Using this form, students self-evaluate their competence in five areas: (1) language proficiency; (2) attitude; (3) awareness; (4) skills; and (5) knowledge. The pre- and post-survey contained the same questions, and were adapted to fit the context of the VE using the EP platform (Appendix 2). The 0-5 scale (ranking from 'no competence' to 'very high competence') was changed to a 1-6 scale (ranking from 'strongly disagree' to 'strongly agree') to avoid neutral options (see also Schenker, 2012) 7 . While Fantini's (2000) original YOGA form assesses four levels (educational traveler, sojourner, professional, and intercultural/multicultural specialist), only the questions assessing the first two were included in the adapted version.

A Shapiro-Wilk test was conducted on the difference between the paired variables of the pre- and post-surveys to analyze the normality of the distributions and establish whether parametric tests could be used ${ }^{8}$. The collected data for all variables was normally distributed with the chosen alpha level 0.05 (Table 1). Next, a paired samples t-test was performed to determine whether the mean differences between paired observations were significantly different. Finally, qualitative data from the blogs further illustrates how EP contributed to students' self-assessments of IC.

Table 1. Normality of distributions test survey US students

\begin{tabular}{|l|l|}
\hline Variable & Shapiro-Wilk $p=$ \\
\hline Language (POST-PRE) & 0.914 \\
\hline Attitude (POST-PRE) & 0.062 \\
\hline Awareness (POST-PRE) & 0.951 \\
\hline Skills (POST-PRE) & 0.580 \\
\hline Knowledge (POST-PRE) & 0.904 \\
\hline
\end{tabular}

6. The YOGA form is a self-assessment guide that can help individuals examine their level of IC before, during, and after an intercultural event (Fantini, 2000).

7. The scale is: (1) strongly disagree, (2) disagree, (3) somewhat disagree, (4) somewhat agree, (5) agree, and (6) strongly agree.

8. The Shapiro-Wilk test (Shapiro \& Wilk, 1965) tests the null hypothesis that a sample is derived from a normally distributed population. 


\section{Data analysis}

Before and after participating in the VE program, the US students self-assessed their competences in the five factors of IC. They rated their IC reasonably high both before and after the videoconference exchange (Table 2). The mean on all categories in both pre- and post-survey oscillates between the 'somewhat agree' to the 'agree' rankings of the scale.

Table 2. Summary of descriptive statistics for self-assessment of IC

\begin{tabular}{|l|l|l|}
\hline Factor & Mean & Std. Error \\
\hline Language Proficiency PRE & 4.6000 & 0.1483 \\
\hline Language Proficiency POST & 4.9583 & 0.1233 \\
\hline Attitude PRE & 5.5833 & 0.0929 \\
\hline Attitude POST & 5.5298 & 0.0936 \\
\hline Awareness PRE & 4.8385 & 0.1306 \\
\hline Awareness POST & 5.0104 & 0.1419 \\
\hline Skills PRE & 4.7458 & 0.1054 \\
\hline Skills POST & 5.0333 & 0.1192 \\
\hline Knowledge PRE & 4.1607 & 0.1512 \\
\hline Knowledge POST & 4.8869 & 0.1365 \\
\hline
\end{tabular}

Regarding the 'language proficiency' component, the students ( $n=24)$ scored an average of 4.60 on the items in the pre-survey, and increased that score up to 4.9583 in the post-survey. The paired t-test showed a statistically significant effect on this variable $(p=.002)$ at a significance level of 0.05 (Table 3).

An analysis of the individual items in this category shows considerable improvements (post-survey mean at least 0.5 points above the pre-survey mean) in the way students perceived their abilities to: (1) communicate tasks requiring a simple and direct exchange of information on familiar topics and activities; (2) deal with most situations likely to arise while traveling in an area where the target language is spoken; (3) explain a viewpoint on a topical issue; and (4) write an essay or report, passing on information or giving reasons in support of or against a particular view.

Indeed, in their final reflection blog, most students mentioned how the video calls helped them feel more confident about their language skills and their abilities to speak to native speakers:

"I know that I still have to practice a lot to master the language, but this opportunity has helped me a great deal, especially because one of my biggest struggles (apart from grammar) 
is to understand native speakers. Through this program, I was able to practice my listening and speaking skills with a native speaker who conversed with me in a casual way [...] Besides, I have learned to use 'fillers' in Spanish which makes me sound more native” (Student 2, Extract Blog 4) ${ }^{9}$.

Table 3. Paired t-test composite variables

\begin{tabular}{|l|l|l|l|l|l|l|l|l|}
\hline & Mean & $\begin{array}{l}\text { St. } \\
\text { Deviation }\end{array}$ & $\begin{array}{l}\text { St. Mean } \\
\text { Error }\end{array}$ & \multicolumn{2}{|l|}{$\begin{array}{l}\text { 95\% Confidence } \\
\text { Interval of Difference }\end{array}$} & t & df & $\begin{array}{l}\text { Sig. } \\
\text { (two-tailed) }\end{array}$ \\
\hline $\begin{array}{l}\text { Pair: Language PRE- } \\
\text { Language POST }\end{array}$ & -0.35833 & 0.50512 & 0.10311 & -0.57163 & -0.14504 & -3.475 & 23 & 0.002 \\
\hline $\begin{array}{l}\text { Pair: Attitude PRE- } \\
\text { Attitude POST }\end{array}$ & 0.05357 & 0.43333 & 0.08845 & -0.12941 & 0.23655 & 0.606 & 23 & 0.551 \\
\hline $\begin{array}{l}\text { Pair: Awareness PRE- } \\
\text { Awareness POST }\end{array}$ & -0.17188 & 0.68546 & 0.13992 & -0.46132 & 0.11757 & -1.228 & 23 & 0.232 \\
\hline $\begin{array}{l}\text { Pair: Skills PRE- } \\
\text { Skills POST }\end{array}$ & -0.28750 & 0.52859 & 0.10790 & -0.51070 & -0.06430 & -2.665 & 23 & 0.014 \\
\hline $\begin{array}{l}\text { Pair: Knowledge PRE- } \\
\text { Knowledge POST }\end{array}$ & -0.72619 & 0.69593 & 0.14206 & -1.02006 & -0.43232 & -5.112 & 23 & 0.000 \\
\hline
\end{tabular}

The means for the 'attitude' variable were very high on both surveys, and they were not significantly different ( $p=.551$ ) (Table 2 and Table 3 ). No items included in the 'attitude' category changed substantially after the exchange program. The high scores recorded in the pre-survey and the lack of change in the post-survey shows that the willingness of the students to communicate and behave appropriately when interacting with their partners remained intact throughout the program.

There was also no statistically significant effect on the overall mean of the 'awareness' variable. However, two items of this category were considerably different between the pre- and post-survey, namely the students' abilities to become aware of: (1) how they are seen by their partners and (2) differences (i.e. diversity aspects such as race, class, gender, age, ability, sexual orientation, etc.) within their partner's culture. In their reflection blogs, students emphasized the effect these exchanges had not only on their comprehension of Colombian life and culture, but also on their insights about their own:

9. All blog quotes are translated from Spanish by the author. 
"I have learned a lot about the life and culture of Colombian students. It is very interesting to compare the lives of Colombians to American students. The differences between routines are vast, but there are many similarities too" (Student 22, Extract Blog 4).

"This opportunity to talk to a student in Colombia about current social issues and cultural topics has changed the way I see my own country and, overall, my life” (Student 25, Extract Blog 4).

The students' self-assessment on the 'skills' variable increased from a pre-survey mean of 4.7458 to a post-survey mean of 5.0333. The paired t-test showed a statistically significant effect on this variable $(p=.014)$. Among the changes detected in this category, two individual items stand out: (1) the ability to contrast their partner's culture with their own and (2) the capacity to name sociopolitical factors which have shaped both their partner's culture and their own. As shown in the blogs, students were aware of the effect of this VE program not only on their language skills, but also on their intercultural and interpersonal skills to communicate with students from a different culture:

"The program demands that I practice my interpersonal skills with someone who speaks Spanish [...] in an environment that I feel comfortable with” (Student 21, Extract Blog 4).

Finally, the 'knowledge' component presented a remarkable increase on the post-survey score. The mean changed from a timid 4.1607 - equivalent to 'somewhat agree' - to a 4.8869 - equivalent to 'agree'. The paired t-test confirmed a statistically significant effect on this variable $(p=.000)$. All items contained in this category showed substantial increases between the pre- and post-surveys. The results highlight the increase of the student's abilities to (1) contrast aspects between both languages and cultures; (2) know essential norms and taboos of their partner's culture; (3) describe and explain both their own and their partner's behavior in various domains; and (4) articulate the general history and sociopolitical factors which have shaped both cultures.

These quantitative results are confirmed qualitatively. During the third week of classes, students reflected on their knowledge about the chosen cultural topics using adjectives like: 'vague', 'minimal', 'poor', 'low', 'slight', and 'decent'. These descriptions contrast with the positive perception about their knowledge shown by the majority of students in their last reflection blogs:

“Finally, my 'amiga' asked me about what I had learned (in the program) and, honestly, it was difficult to give her a succinct answer. The truth is that I have learned so much and I have enjoyed it much more than I thought at the beginning. The program has given me 
a new perspective on Colombia. Here in the United States, we always hear of the dangers, risks, and drugs of Colombia, but rarely of this country's fascinating culture and beauty” (Student 20, Extract Blog 4).

Some students also became aware of their lack of knowledge of other countries' worldviews, and saw this experience as a starting point to continue investigating, especially in the topics of interest to them:

"I want to know more about the major environmental problems of other countries. Through the [EP] experience, I have come to realize that every country has a different approach about what is urgent in terms of environmental policies. I hope these conversations become a launching point for me to explore the different outlooks in other parts of the world" (Student 26, Extract Blog 4).

\section{Conclusions}

This report presented the effectiveness of using an EP that manages the administrative aspects of partnering trained native speakers with Spanish language learners as an alternative approach to the traditional practitioner-led telecollaboration setting. The use of an EP instead of a tandem partnership with a foreign higher education institution brings an undeniable level of flexibility to the organization of VE, and makes manageable the integration of this type of programs in language classes. During the eight-week cross-cultural VE between US and Colombian college students, it was possible to concentrate efforts into the task design, selection of topics, and the management of the different curricular components of the course (class preparation, class discussions, creation of assignments, grading, etc.). Meanwhile, most technical and technological arrangements and assistance were delegated to the EP staff. Time-consuming processes, including the selection of Colombian students, the matching of 'learners' with partners, the scheduling of video conferences, the resolution of unexpected time and technical conflicts, and the recording of the videoconference sessions throughout the exchange were all managed by the EP team.

This study also explored the effectiveness of this program on the US students' development of IC. Focusing on their self-assessment of IC before and after the videoconference exchanges through quantitative and qualitative data collection, the analysis shows a significant increase on the student's IC after the program. The US students perceived a significant effect on their language proficiency, skills, knowledge, and awareness of how their Columbian exchange partner sees them and the differences within South American/Columbian culture. 
While the preliminary assessment of blogs and individual presentations confirms the positive effect of these exchanges on the IC areas mentioned above, the difficulty to obtain a reliable account of the initial level of the students on these different categories remains an important obstacle. For instance, in the third week of classes, students provided a written account on their familiarity and knowledge about the topics that they wanted to discuss with their partners. However, their answers were vague and elusive. Most students mentioned that their knowledge was basic, but did not provide specific information. The voluntary nature of these questions and the likely apprehension to make a mistake about an issue for which they had not previously prepared, makes this initial stage of the study challenging. Therefore, it seems necessary to conduct more qualitative analysis in order to corroborate the students' initial self-evaluations of their IC to further prove the effect of these exchanges on the students' IC.

Finally, it must not be forgotten that EP is a fee-paying service. While the information collected does not indicate that the price had a significant impact on the student's attitude toward the service, more research is needed to establish the effect on the students' perceptions of their IC development using a fee-paying service versus alternatives, taking into account variables such as socio-economic background or institutional support.

\section{References}

Byram, M. (1997). Teaching and assessing intercultural communicative competence. Multilingual Matters.

Deardorff, D. K. (2004). In search of intercultural competence. International Educator, 13(2), 13-15.

Fantini, A. E. (2000). A central concern: developing intercultural competence. SIT Occasional Papers Series: Addressing Intercultural Education, Training and Service, 1, 25-42.

Fantini, A. E. (2009). Assessing intercultural competence: issues and tools. In D. K. Deardorff (Ed.), The SAGE handbook of intercultural competence (pp. 456-477). Sage.

Ferreira-Lopes, L., Bezanilla, M. J., \& Elexpuru, I. (2018). Integrating intercultural competence development into the curriculum through telecollaboration. A task sequence proposal for higher education. RED. Revista de Educación a Distancia, 58(7), 2-36. https://doi.org/10.6018/red/58/7.

Helm, F. (2015). The practices and challenges of telecollaboration in higher education in Europe. Language Learning \& Technology, 19(2), 197-217. http://lit.msu.edu/issues/june2015/helm.pdf

Liaw, M. (2006). E-learning and the development of intercultural competence. Language Learning \& Technology, 10(3), 49-64. http://lt.msu.edu/vol10num3/liaw/

O’Dowd, R. (2007). Evaluating the outcomes of online intercultural exchange. ELT Journal, 61(2), 144-152. https://doi. org/10.1093/elt/ccm007 
O’Dowd, R. (2018). From telecollaboration to virtual exchange: state-of-the-art and the role of UNICollaboration in moving forward. Journal of Virtual Exchange, 1, 1-23. https://doi.org/10.14705/rpnet.2018.jve.1

Schenker, T. (2012). The effects of a virtual exchange on language skills and intercultural competence. Dissertation. Michigan State University.

Shapiro, S., \& Wilk, M. (1965). An analysis of variance test for normality (complete samples). Biometrika, 52(3/4), 591-611.

Vinagre, M. (2014). El desarrollo de la competencia intercultural en los intercambios telecolaborativos. RED. Revista de Educación a Distancia, 41, 1-22. https://repositorio.uam.es/handle/10486/669610 


\section{Virtual Exchange?}

Published by University of Groningen Press | UGP, a not-for-profit press

Groningen, The Netherlands | UGP@rug.nl

(C) 2021 UNICollaboration (collective work)

(C) 2021 by Authors (individual work)

Journal of Virtual Exchange 2021

Edited by Carolin Fuchs and Müge Satar

Publication date: 2021/02/03

Journal of Virtual Exchange (JVE) is an online, open-access, peer-reviewed journal aimed at practitioners and researchers in the field known variously as virtual exchange, telecollaboration, or online intercultural exchange. It is the official journal of UNICollaboration (https://www.UNICollaboration.org/), the international academic organisation dedicated to supporting and promoting telecollaboration and virtual exchange in higher-level education.

Rights. The whole volume is published under the Attribution-NonCommercial-NoDerivatives 4.0 International licence (CC BY-NCND 4.0); individual articles may have a different licence. Under the CC BY-NC-ND licence, the volume is freely available online for anybody to read, download, copy, and redistribute provided that the author(s), editorial team, and publisher are properly cited. Commercial use and derivative works are, however, not permitted.

Disclaimer. University of Groningen Press does not take any responsibility for the content of the pages written by the authors of this article. The authors have recognised that the work described was not published before, or that it was not under consideration for publication elsewhere. While the information in this article is believed to be true and accurate on the date of its going to press, neither UniCollaboration nor University of Groningen Press can accept any legal responsibility for any errors or omissions. Additionally, the publisher makes no warranty, expressed or implied, with respect to the material contained herein. While University of Groningen Press is committed to publishing works of integrity, the words are the authors' alone.

Trademark notice. Product or corporate names may be trademarks or registered trademarks, and are used only for identification and explanation without intent to infringe.

Copyrighted material. Every effort has been made by the editorial team to trace copyright holders and to obtain their permission for the use of copyrighted material in this article. In the event of errors or omissions, please notify the publisher of any corrections that will need to by incorporated in future editions of this article.

Typeset by Research-publishing.net (https://research-publishing.net)

Noto fonts are open source. All Noto fonts are published under the SIL Open Font License, Version 1.1. Noto is a trademark of Google Inc. (https://www.google.com/get/noto/).

ISSN: 2647-4832 (online only)

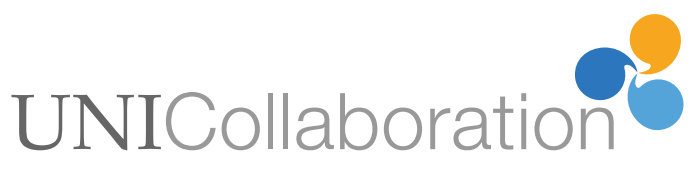




\section{Temas culturales}

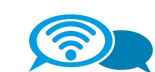

Language Amigo

1. Deportes populares

2. Celebraciones y festividades

3. La religión: costumbres y creencias religiosas

4. La vida universitaria (número de clases, estilo de exámenes, calificaciones, número de estudiantes, las materias, etc.)

5. El cine y la literatura de la región o el país. Las artes visuales y plásticas

6. La música (bailes tradicionales y modernos)

7. La vida familiar

8. La vida diaria (impacto de la tecnología en las relaciones sociales) y las relaciones personales (costumbres sociales)

9. La situación política del país

10. Moda, ropa y expresión personal

11. La naturaleza de la región (problemas de contaminación, etc.)

12. Gastronomía

13. Relaciones con países vecinos

14. Brecha generacional y cambios significativos en el país y la sociedad de origen durante las últimas dos décadas

15. La diversidad racial y étnica

16. El mundo laboral

17. La situación de la mujer

18. Objetivos vitales y la perspectiva de la felicidad

19. Comportamientos culturales, creencias y hábitos

20. Estereotipos sobre los americanos y los estereotipos que los colombianos creen que los estadounidenses tienen de ellos

21. Conflictos armados (guerrillas) 
Appendix 2: Assessing Intercultural Competence (AIC) ${ }^{1}$

This assessment is anonymous and not for grading purposes.

\section{ASSESSING INTERCULTURAL COMPETENCE}

Please indicate your agreement/disagreement with the following statements by choosing:

(1) strongly disagree (2) disagree (3) somewhat disagree (4) somewhat agree (5) agree (6) strongly agree

\section{LANGUAGE PROFICIENCY (SPANISH)}

\begin{tabular}{|c|c|c|c|c|c|c|}
\hline $\begin{array}{l}\text { 1. I can understand familiar words and very } \\
\text { basic phrases concerning myself, my family } \\
\text { and immediate concrete surroundings when } \\
\text { people speak slowly and clearly. I can } \\
\text { understand familiar names, words and very } \\
\text { simple sentences, for example on notices and } \\
\text { posters or in catalogues. }\end{array}$ & $\begin{array}{c}1 \\
\text { Strongly } \\
\text { Disagree }\end{array}$ & 2 & 3 & 4 & 5 & $\begin{array}{l}6 \\
\text { Strongly } \\
\text { Agree }\end{array}$ \\
\hline $\begin{array}{l}\text { 2. I can understand familiar names, words } \\
\text { and very simple sentences, for example on } \\
\text { notices and posters or in catalogues. }\end{array}$ & $\begin{array}{c}1 \\
\text { Strongly } \\
\text { Disagree }\end{array}$ & 2 & 3 & 4 & 5 & $\begin{array}{l}6 \\
\text { Strongly } \\
\text { Agree }\end{array}$ \\
\hline $\begin{array}{l}\text { 3. I can interact in a simple way provided the } \\
\text { other person is prepared to repeat or } \\
\text { rephrase things at a slower rate of speech } \\
\text { and help me formulate what I'm trying to say. } \\
\text { I can ask and answer simple questions in } \\
\text { areas of immediate need or on very familiar } \\
\text { topics. }\end{array}$ & $\begin{array}{c}1 \\
\text { Strongly } \\
\text { Disagree }\end{array}$ & 2 & 3 & 4 & 5 & $\begin{array}{l}6 \\
\text { Strongly } \\
\text { Agree }\end{array}$ \\
\hline $\begin{array}{l}\text { 4. I can use simple phrases and sentences to } \\
\text { describe where I live and people I know. }\end{array}$ & $\begin{array}{c}1 \\
\text { Strongly } \\
\text { Disagree }\end{array}$ & 2 & 3 & 4 & 5 & $\begin{array}{l}6 \\
\text { Strongly } \\
\text { Agree }\end{array}$ \\
\hline $\begin{array}{l}\text { 5. I can write a short, simple postcard, for } \\
\text { example sending holiday greetings. I can fill in } \\
\text { forms with personal details, for example } \\
\text { entering my name, nationality and address on } \\
\text { a hotel registration form. }\end{array}$ & $\begin{array}{c}1 \\
\text { Strongly } \\
\text { Disagree }\end{array}$ & 2 & 3 & 4 & 5 & $\begin{array}{l}6 \\
\text { Strongly } \\
\text { Agree }\end{array}$ \\
\hline
\end{tabular}

\footnotetext{
${ }^{1}$ Adapted from the YOGA (Your Objectives, Guidelines, and Assessment) form for assessing IC developed by Alvino E. Fantini.
} 


\begin{tabular}{|c|c|c|c|c|c|c|}
\hline $\begin{array}{l}\text { 6. I can understand phrases and the highest } \\
\text { frequency vocabulary related to areas of } \\
\text { most immediate personal relevance (e.g. very } \\
\text { basic personal and family information, } \\
\text { shopping, local area, employment). I can } \\
\text { catch the main point in short, clear, simple } \\
\text { messages and announcements. }\end{array}$ & $\begin{array}{c}1 \\
\text { Strongly } \\
\text { Disagree }\end{array}$ & 2 & 3 & 4 & 5 & $\begin{array}{l}6 \\
\text { Strongly } \\
\text { Agree }\end{array}$ \\
\hline $\begin{array}{l}\text { 7. I can read very short, simple texts. I can } \\
\text { find specific, predictable information in } \\
\text { simple everyday material such as } \\
\text { advertisements, prospectuses, menus and } \\
\text { timetables and I can understand short simple } \\
\text { personal letters. }\end{array}$ & $\begin{array}{c}1 \\
\text { Strongly } \\
\text { Disagree }\end{array}$ & 2 & 3 & 4 & 5 & $\begin{array}{l}6 \\
\text { Strongly } \\
\text { Agree }\end{array}$ \\
\hline $\begin{array}{l}\text { 8. I can communicate in simple and routine } \\
\text { tasks requiring a simple and direct exchange } \\
\text { of information on familiar topics and } \\
\text { activities. I can handle very short social } \\
\text { exchanges, even though I can't usually } \\
\text { understand enough to keep the conversation } \\
\text { going myself. }\end{array}$ & $\begin{array}{c}1 \\
\text { Strongly } \\
\text { Disagree }\end{array}$ & 2 & 3 & 4 & 5 & $\begin{array}{l}6 \\
\text { Strongly } \\
\text { Agree }\end{array}$ \\
\hline $\begin{array}{l}\text { 9. I can use a series of phrases and sentences } \\
\text { to describe in simple terms my family and } \\
\text { other people, living conditions, my } \\
\text { educational background and my present or } \\
\text { most recent job. }\end{array}$ & $\begin{array}{c}1 \\
\text { Strongly } \\
\text { Disagree }\end{array}$ & 2 & 3 & 4 & 5 & $\begin{array}{l}6 \\
\text { Strongly } \\
\text { Agree }\end{array}$ \\
\hline $\begin{array}{l}\text { 10. I can write short, simple notes and } \\
\text { messages. I can write a very simple personal } \\
\text { letter, for example thanking someone for } \\
\text { something. }\end{array}$ & $\begin{array}{c}1 \\
\text { Strongly } \\
\text { Disagree }\end{array}$ & 2 & 3 & 4 & 5 & $\begin{array}{l}6 \\
\text { Strongly } \\
\text { Agree }\end{array}$ \\
\hline $\begin{array}{l}\text { 11. I can understand the main points of clear } \\
\text { standard speech on familiar matters regularly } \\
\text { encountered in work, school, leisure, etc. I } \\
\text { can understand the main point of many radio } \\
\text { or TV programs on current affairs or topics of } \\
\text { personal or professional interest when the } \\
\text { delivery is relatively slow and clear. }\end{array}$ & $\begin{array}{c}1 \\
\text { Strongly } \\
\text { Disagree }\end{array}$ & 2 & 3 & 4 & 5 & $\begin{array}{l}6 \\
\text { Strongly } \\
\text { Agree }\end{array}$ \\
\hline
\end{tabular}




\begin{tabular}{|c|c|c|c|c|c|c|}
\hline $\begin{array}{l}\text { 12. I can understand texts that consist mainly } \\
\text { of high frequency everyday or job-related } \\
\text { language. I can understand the description of } \\
\text { events, feelings and wishes in personal } \\
\text { letters. }\end{array}$ & $\begin{array}{c}1 \\
\text { Strongly } \\
\text { Disagree }\end{array}$ & 2 & 3 & 4 & 5 & $\begin{array}{l}6 \\
\text { Strongly } \\
\text { Agree }\end{array}$ \\
\hline $\begin{array}{l}\text { 13. I can deal with most situations likely to } \\
\text { arise whilst travelling in an area where the } \\
\text { language is spoken. I can enter unprepared } \\
\text { into conversation on topics that are familiar, } \\
\text { of personal interest or pertinent to everyday } \\
\text { life (e.g. family, hobbies, work, travel and } \\
\text { current events). }\end{array}$ & $\begin{array}{c}1 \\
\text { Strongly } \\
\text { Disagree }\end{array}$ & 2 & 3 & 4 & 5 & $\begin{array}{l}6 \\
\text { Strongly } \\
\text { Agree }\end{array}$ \\
\hline $\begin{array}{l}\text { 14. I can connect phrases in a simple way in } \\
\text { order to describe experiences and events, my } \\
\text { dreams, hopes and ambitions. I can briefly } \\
\text { give reasons and explanations for opinions } \\
\text { and plans. I can narrate a story or relate the } \\
\text { plot of a book or film and describe my } \\
\text { reactions. }\end{array}$ & $\begin{array}{c}1 \\
\text { Strongly } \\
\text { Disagree }\end{array}$ & 2 & 3 & 4 & 5 & $\begin{array}{l}6 \\
\text { Strongly } \\
\text { Agree }\end{array}$ \\
\hline $\begin{array}{l}\text { 15. I can write simple connected text on } \\
\text { topics which are familiar or of personal } \\
\text { interest. I can write personal letters } \\
\text { describing experiences and impressions. }\end{array}$ & $\begin{array}{c}1 \\
\text { Strongly } \\
\text { Disagree }\end{array}$ & 2 & 3 & 4 & 5 & $\begin{array}{l}6 \\
\text { Strongly } \\
\text { Agree }\end{array}$ \\
\hline $\begin{array}{l}\text { 16. I can understand extended speech and } \\
\text { lectures and follow even complex lines of } \\
\text { argument provided the topic is reasonably } \\
\text { familiar. I can understand most TV news and } \\
\text { current affairs programs. I can understand } \\
\text { the majority of films in standard dialect. }\end{array}$ & $\begin{array}{c}1 \\
\text { Strongly } \\
\text { Disagree }\end{array}$ & 2 & 3 & 4 & 5 & $\begin{array}{l}6 \\
\text { Strongly } \\
\text { Agree }\end{array}$ \\
\hline $\begin{array}{l}\text { 17. I can read articles and reports concerned } \\
\text { with contemporary problems in which the } \\
\text { writers adopt particular attitudes or } \\
\text { viewpoints. I can understand contemporary } \\
\text { literary prose. }\end{array}$ & $\begin{array}{c}1 \\
\text { Strongly } \\
\text { Disagree }\end{array}$ & 2 & 3 & 4 & 5 & $\begin{array}{l}6 \\
\text { Strongly } \\
\text { Agree }\end{array}$ \\
\hline
\end{tabular}




\begin{tabular}{|c|c|c|c|c|c|c|}
\hline $\begin{array}{l}\text { 18. I can interact with a degree of fluency and } \\
\text { spontaneity that makes regular interaction } \\
\text { with native speakers quite possible. I can take } \\
\text { an active part in discussion in familiar } \\
\text { contexts, accounting for and sustaining my } \\
\text { views. }\end{array}$ & $\begin{array}{c}1 \\
\text { Strongly } \\
\text { Disagree }\end{array}$ & 2 & 3 & 4 & 5 & $\begin{array}{l}6 \\
\text { Strongly } \\
\text { Agree }\end{array}$ \\
\hline $\begin{array}{l}\text { 19. I can present clear, detailed descriptions } \\
\text { on a wide range of subjects related to my } \\
\text { field of interest. I can explain a viewpoint on a } \\
\text { topical issue giving the advantages and } \\
\text { disadvantages of various options. }\end{array}$ & $\begin{array}{c}1 \\
\text { Strongly } \\
\text { Disagree }\end{array}$ & 2 & 3 & 4 & 5 & $\begin{array}{l}6 \\
\text { Strongly } \\
\text { Agree }\end{array}$ \\
\hline $\begin{array}{l}\text { 20. I can write clear, detailed text on a wide } \\
\text { range of subjects related to my interests. I } \\
\text { can write an essay or report, passing on } \\
\text { information or giving reasons in support of or } \\
\text { against a particular point of view. I can write } \\
\text { letters highlighting the personal significance } \\
\text { of events and experiences. }\end{array}$ & $\begin{array}{c}1 \\
\text { Strongly } \\
\text { Disagree }\end{array}$ & 2 & 3 & 4 & 5 & $\begin{array}{l}6 \\
\text { Strongly } \\
\text { Agree }\end{array}$ \\
\hline
\end{tabular}

\section{ATTITUDE: I AM WILLING TO....}

\begin{tabular}{|c|c|c|c|c|c|c|}
\hline $\begin{array}{l}\text { 1. ...communicate with my exchange partner } \\
\text { from Colombia }\end{array}$ & $\begin{array}{l}1 \\
\text { Strongly } \\
\text { Disagree }\end{array}$ & 2 & 3 & 4 & 5 & $\begin{array}{l}6 \\
\text { Strongly } \\
\text { Agree }\end{array}$ \\
\hline $\begin{array}{l}\text { 2. ...learn language and culture from my } \\
\text { Colombian exchange partner }\end{array}$ & $\begin{array}{l}1 \\
\text { Strongly } \\
\text { Disagree }\end{array}$ & 2 & 3 & 4 & 5 & $\begin{array}{l}6 \\
\text { Strongly } \\
\text { Agree }\end{array}$ \\
\hline $\begin{array}{l}\text { 3. ...try to communicate in Spanish with my } \\
\text { exchange partner and behave in ways judged } \\
\text { "appropriate" by South American/Colombian } \\
\text { culture }\end{array}$ & $\begin{array}{l}1 \\
\text { Strongly } \\
\text { Disagree }\end{array}$ & 2 & 3 & 4 & 5 & $\begin{array}{l}6 \\
\text { Strongly } \\
\text { Agree }\end{array}$ \\
\hline $\begin{array}{l}\text { 4. ...try to deal with the emotions and } \\
\text { frustrations caused by my participation in the } \\
\text { videoconference exchange }\end{array}$ & $\begin{array}{l}1 \\
\text { Strongly } \\
\text { Disagree }\end{array}$ & 2 & 3 & 4 & 5 & $\begin{array}{l}6 \\
\text { Strongly } \\
\text { Agree }\end{array}$ \\
\hline $\begin{array}{l}\text { 5. ...show interest in particular aspects of } \\
\text { South American/Colombian culture }\end{array}$ & $\begin{array}{l}1 \\
\text { Strongly } \\
\text { Disagree }\end{array}$ & 2 & 3 & 4 & 5 & $\begin{array}{l}6 \\
\text { Strongly } \\
\text { Agree }\end{array}$ \\
\hline
\end{tabular}




\begin{tabular}{|c|c|c|c|c|c|c|}
\hline $\begin{array}{l}\text { 6. ....adapt my behavior in accordance to what } \\
\text { I am learning about communication in South } \\
\text { American/Colombian culture }\end{array}$ & $\begin{array}{c}1 \\
\text { Strongly } \\
\text { Disagree }\end{array}$ & 2 & 3 & 4 & 5 & $\begin{array}{l}6 \\
\text { Strongly } \\
\text { Agree }\end{array}$ \\
\hline $\begin{array}{l}\text { 7. ... reflect on the impact and consequences } \\
\text { of my decisions, choices, and behavior on my } \\
\text { Colombian exchange partner }\end{array}$ & $\begin{array}{c}1 \\
\text { Strongly } \\
\text { Disagree }\end{array}$ & 2 & 3 & 4 & 5 & $\begin{array}{l}6 \\
\text { Strongly } \\
\text { Agree }\end{array}$ \\
\hline
\end{tabular}

AWARENESS: I AM AWARE OF....

\begin{tabular}{|c|c|c|c|c|c|c|}
\hline 1....differences across languages and cultures & $\begin{array}{l}1 \\
\text { Strongly } \\
\text { Disagree }\end{array}$ & 2 & 3 & 4 & 5 & $\begin{array}{l}6 \\
\text { Strongly } \\
\text { Agree }\end{array}$ \\
\hline 2. ...my reactions to these differences & $\begin{array}{c}1 \\
\text { Strongly } \\
\text { Disagree }\end{array}$ & 2 & 3 & 4 & 5 & $\begin{array}{l}6 \\
\text { Strongly } \\
\text { Agree }\end{array}$ \\
\hline $\begin{array}{l}\text { 3. ...how a specific context impacts my } \\
\text { interaction with others }\end{array}$ & $\begin{array}{l}1 \\
\text { Strongly } \\
\text { Disagree }\end{array}$ & 2 & 3 & 4 & 5 & $\begin{array}{l}6 \\
\text { Strongly } \\
\text { Agree }\end{array}$ \\
\hline $\begin{array}{l}\text { 4. ...how my Colombian exchange partner will } \\
\text { see me }\end{array}$ & $\begin{array}{c}1 \\
\text { Strongly } \\
\text { Disagree }\end{array}$ & 2 & 3 & 4 & 5 & $\begin{array}{l}6 \\
\text { Strongly } \\
\text { Agree }\end{array}$ \\
\hline $\begin{array}{l}\text { 5...how I am viewed by members of my own } \\
\text { culture }\end{array}$ & $\begin{array}{c}1 \\
\text { Strongly } \\
\text { Disagree }\end{array}$ & 2 & 3 & 4 & 5 & $\begin{array}{l}6 \\
\text { Strongly } \\
\text { Agree }\end{array}$ \\
\hline $\begin{array}{l}\text { 6....differences (i.e., diversity aspects such as } \\
\text { race, class, gender, age, ability, sexual } \\
\text { orientation, etc.) within my own culture }\end{array}$ & $\begin{array}{c}1 \\
\text { Strongly } \\
\text { Disagree }\end{array}$ & 2 & 3 & 4 & 5 & $\begin{array}{l}6 \\
\text { Strongly } \\
\text { Agree }\end{array}$ \\
\hline $\begin{array}{l}\text { 7...differences (i.e., diversity aspects such as } \\
\text { race, class, gender, age, ability, sexual } \\
\text { orientation, etc.) within South } \\
\text { American/Colombian culture }\end{array}$ & $\begin{array}{c}1 \\
\text { Strongly } \\
\text { Disagree }\end{array}$ & 2 & 3 & 4 & 5 & $\begin{array}{l}6 \\
\text { Strongly } \\
\text { Agree }\end{array}$ \\
\hline $8 \ldots .$. my choices and their consequences & $\begin{array}{l}1 \\
\text { Strongly } \\
\text { Disagree }\end{array}$ & 2 & 3 & 4 & 5 & $\begin{array}{l}6 \\
\text { Strongly } \\
\text { Agree }\end{array}$ \\
\hline
\end{tabular}




\begin{tabular}{|c|c|c|c|c|c|c|}
\hline $\begin{array}{l}\text { 1. I will be flexible when interacting with my } \\
\text { Colombian exchange partner }\end{array}$ & $\begin{array}{c}1 \\
\text { Strongly } \\
\text { Disagree }\end{array}$ & 2 & 3 & 4 & 5 & $\begin{array}{l}6 \\
\text { Strongly } \\
\text { Agree }\end{array}$ \\
\hline $\begin{array}{l}\text { 2. I know how not to offend my Colombian } \\
\text { exchange partner with my (verbal) behavior }\end{array}$ & $\begin{array}{l}1 \\
\text { Strongly } \\
\text { Disagree }\end{array}$ & 2 & 3 & 4 & 5 & $\begin{array}{l}6 \\
\text { Strongly } \\
\text { Agree }\end{array}$ \\
\hline $\begin{array}{l}\text { 3. I am able to contrast South } \\
\text { American/Colombian culture with my own }\end{array}$ & $\begin{array}{l}1 \\
\text { Strongly } \\
\text { Disagree }\end{array}$ & 2 & 3 & 4 & 5 & $\begin{array}{l}6 \\
\text { Strongly } \\
\text { Agree }\end{array}$ \\
\hline $\begin{array}{l}\text { 4. I use strategies which aid my } \\
\text { communication \& reduce misunderstandings } \\
\text { when communicating with my Colombian } \\
\text { exchange partner }\end{array}$ & $\begin{array}{c}1 \\
\text { Strongly } \\
\text { Disagree }\end{array}$ & 2 & 3 & 4 & 5 & $\begin{array}{l}6 \\
\text { Strongly } \\
\text { Agree }\end{array}$ \\
\hline $\begin{array}{l}\text { 5. I develop strategies for learning the } \\
\text { Spanish language and about South } \\
\text { American/Colombian culture }\end{array}$ & $\begin{array}{c}1 \\
\text { Strongly } \\
\text { Disagree }\end{array}$ & 2 & 3 & 4 & 5 & $\begin{array}{l}6 \\
\text { Strongly } \\
\text { Agree }\end{array}$ \\
\hline $\begin{array}{l}\text { 6. I use a variety of effective strategies when } \\
\text { interacting with culturally different people }\end{array}$ & $\begin{array}{c}1 \\
\text { Strongly } \\
\text { Disagree }\end{array}$ & 2 & 3 & 4 & 5 & $\begin{array}{l}6 \\
\text { Strongly } \\
\text { Agree }\end{array}$ \\
\hline $\begin{array}{l}\text { 7. I interact appropriately in conversational } \\
\text { exchange with my Colombian exchange } \\
\text { partner }\end{array}$ & $\begin{array}{c}1 \\
\text { Strongly } \\
\text { Disagree }\end{array}$ & 2 & 3 & 4 & 5 & $\begin{array}{l}6 \\
\text { Strongly } \\
\text { Agree }\end{array}$ \\
\hline $\begin{array}{l}\text { 8. I can name sociopolitical factors which } \\
\text { have shaped both my own and South } \\
\text { American/Colombian culture }\end{array}$ & $\begin{array}{l}1 \\
\text { Strongly } \\
\text { Disagree }\end{array}$ & 2 & 3 & 4 & 5 & $\begin{array}{l}6 \\
\text { Strongly } \\
\text { Agree }\end{array}$ \\
\hline $\begin{array}{l}\text { 9. I employ appropriate strategies for } \\
\text { adjusting to intercultural exchange. }\end{array}$ & $\begin{array}{c}1 \\
\text { Strongly } \\
\text { Disagree }\end{array}$ & 2 & 3 & 4 & 5 & $\begin{array}{l}6 \\
\text { Strongly } \\
\text { Agree }\end{array}$ \\
\hline $\begin{array}{l}\text { 10. I use appropriate strategies to enhance } \\
\text { my learning about South } \\
\text { American/Colombian culture and language in }\end{array}$ & $\begin{array}{c}1 \\
\text { Strongly } \\
\text { Disagree }\end{array}$ & 2 & 3 & 4 & 5 & $\begin{array}{l}6 \\
\text { Strongly } \\
\text { Agree }\end{array}$ \\
\hline
\end{tabular}


a conversational exchange with nativespeakers.

\section{KNOWLEDGE}

\begin{tabular}{|c|c|c|c|c|c|c|}
\hline $\begin{array}{l}\text { 1. I can give a basic definition of culture and } \\
\text { identify its components }\end{array}$ & $\begin{array}{l}1 \\
\text { Strongly } \\
\text { Disagree }\end{array}$ & 2 & 3 & 4 & 5 & $\begin{array}{l}6 \\
\text { Strongly } \\
\text { Agree }\end{array}$ \\
\hline $\begin{array}{l}\text { 2. I can contrast aspects of Spanish language } \\
\text { and South American/Colombian culture with } \\
\text { my own }\end{array}$ & $\begin{array}{c}1 \\
\text { Strongly } \\
\text { Disagree }\end{array}$ & 2 & 3 & 4 & 5 & $\begin{array}{l}6 \\
\text { Strongly } \\
\text { Agree }\end{array}$ \\
\hline $\begin{array}{l}\text { 3. I know the essential norms and taboos } \\
\text { (greetings, dress, behavior, etc.) of South } \\
\text { American/Colombian culture }\end{array}$ & $\begin{array}{c}1 \\
\text { Strongly } \\
\text { Disagree }\end{array}$ & 2 & 3 & 4 & 5 & $\begin{array}{l}6 \\
\text { Strongly } \\
\text { Agree }\end{array}$ \\
\hline $\begin{array}{l}\text { 4. I know some techniques to maximize my } \\
\text { learning of Spanish language and South } \\
\text { American/Colombian culture }\end{array}$ & $\begin{array}{c}1 \\
\text { Strongly } \\
\text { Disagree }\end{array}$ & 2 & 3 & 4 & 5 & $\begin{array}{l}6 \\
\text { Strongly } \\
\text { Agree }\end{array}$ \\
\hline $\begin{array}{l}5 . \text { I can explain at least one definition of } \\
\text { culture }\end{array}$ & $\begin{array}{l}1 \\
\text { Strongly } \\
\text { Disagree }\end{array}$ & 2 & 3 & 4 & 5 & $\begin{array}{l}6 \\
\text { Strongly } \\
\text { Agree }\end{array}$ \\
\hline $\begin{array}{l}\text { 6. I can describe and explain my own behavior } \\
\text { and that of my Colombian exchange partner } \\
\text { in various domains (e.g., social interaction, } \\
\text { time orientation, relation to the environment, } \\
\text { spiritual, etc.) }\end{array}$ & $\begin{array}{l}1 \\
\text { Strongly } \\
\text { Disagree }\end{array}$ & 2 & 3 & 4 & 5 & $\begin{array}{l}6 \\
\text { Strongly } \\
\text { Agree }\end{array}$ \\
\hline $\begin{array}{l}\text { 7. I can articulate the general history and } \\
\text { some sociopolitical factors which have } \\
\text { shaped my own and South } \\
\text { American/Colombian culture }\end{array}$ & $\begin{array}{c}1 \\
\text { Strongly } \\
\text { Disagree }\end{array}$ & 2 & 3 & 4 & 5 & $\begin{array}{l}6 \\
\text { Strongly } \\
\text { Agree }\end{array}$ \\
\hline
\end{tabular}




\section{This Toolkit covers:}

\section{(2)}

Language Amigo

- Welcome to Language Amigo. .3

- About Language Amigo! .4

- Language Amigo terminology......................................5

- Your journey with Language Amigo! 6

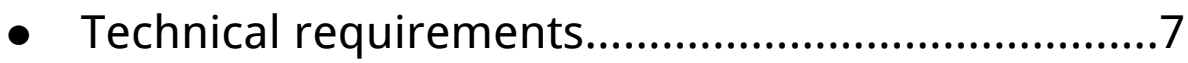

- CNU 302 - 2019 Sessions dates...........................8

- What to expect during your sessions.......................9

- General Tips! .10

- Guidelines to ensure everyone is happy and safe!.11

- Need to reschedule a session?..................................12

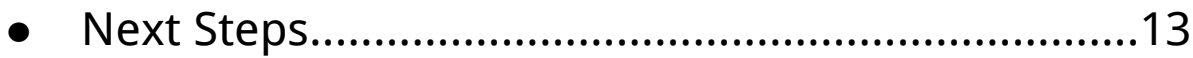

- Appendix 1 - Payment instructions...........................14

- Appendix 2 - If you have a Mac...............................15

- Language Amigo contact details. .16 


\section{Contenido}

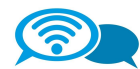

Language Amigo

- Pasos a seguir para tus sesiones de Language

NEW\} Amigo! 3

- Objetivo del programa, fechas y temas

$\{\mathrm{NEW}\}$ sugeridos para CNU 302

- Glosario de términos Language Amigo.........6

- Tips generales................................ 7

- ¡Lineamientos para asegurar que todos estemos felices y seguros!

- ¿Qué pasa si tú o él Learner no se pueden presentar a la sesión?.........................9

- Uso del Calendario de Google.................10 